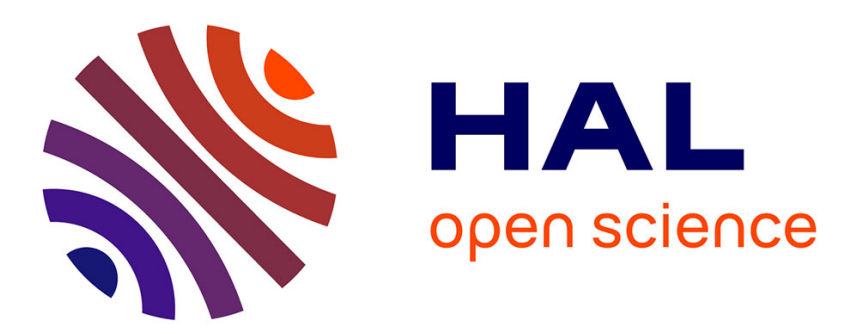

\title{
Combined dynamics of mercury and terrigenous organic matter following impoundment of Churchill Falls Hydroelectric Reservoir, Labrador
}

\author{
Roman Teisserenc, Marc Lucotte, René Canuel, Matthieu Moingt, Daniel
}

Obrist

\section{To cite this version:}

Roman Teisserenc, Marc Lucotte, René Canuel, Matthieu Moingt, Daniel Obrist. Combined dynamics of mercury and terrigenous organic matter following impoundment of Churchill Falls Hydroelectric Reservoir, Labrador. Biogeochemistry, 2013, vol. 118, pp. 21-34. 10.1007/s10533-013-9902-9 . hal01068161

\section{HAL Id: hal-01068161 \\ https://hal.science/hal-01068161}

Submitted on 29 Sep 2014

HAL is a multi-disciplinary open access archive for the deposit and dissemination of scientific research documents, whether they are published or not. The documents may come from teaching and research institutions in France or abroad, or from public or private research centers.
L'archive ouverte pluridisciplinaire HAL, est destinée au dépôt et à la diffusion de documents scientifiques de niveau recherche, publiés ou non, émanant des établissements d'enseignement et de recherche français ou étrangers, des laboratoires publics ou privés. 


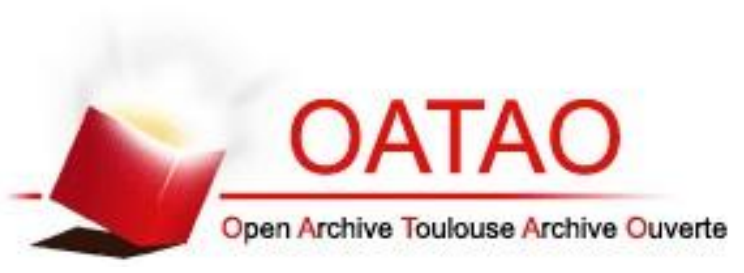

\section{Open Archive Toulouse Archive Ouverte (OATAO)}

OATAO is an open access repository that collects the work of Toulouse researchers and makes it freely available over the web where possible.

This is an author-deposited version published in: http://oatao.univ-toulouse.fr/ Eprints ID: 10284

Identification number: DOI: 10.1007/s10533-013-9902-9

Official URL: http://dx.doi.org/10.1007/s10533-013-9902-9

\section{To cite this version:}

Teisserenc, Roman and Lucotte, Marc and Canuel, René and Moingt, Matthieu and Obrist, Daniel Combined dynamics of mercury and terrigenous organic matter following impoundment of Churchill Falls Hydroelectric Reservoir, Labrador. (2013) Biogeochemistry, vol. 118 ( $\left.\mathrm{n}^{\circ} 1-3\right)$. pp. 21-34. ISSN 01682563

Any correspondence concerning this service should be sent to the repository administrator: staff-oatao@inp-toulouse.fr 


\title{
Combined dynamics of mercury and terrigenous organic matter following impoundment of Churchill Falls Hydroelectric Reservoir, Labrador
}

\author{
Roman Teisserenc • Marc Lucotte • \\ René Canuel · Matthieu Moingt • Daniel Obrist
}

\begin{abstract}
Sediments from two recently (40 years) flooded lakes (Gabbro lake and Sandgirt lake) and an unflooded lake (Atikonak lake) were sampled to investigate the effects of reservoir impoundment on mercury $(\mathrm{Hg})$ and terrigenous organic matter (TOM) loading in the Churchill Falls Hydroelectric complex in Labrador, Canada. Lignin biomarkers in TOM, which exclusively derive from terrestrial vegetation, were used as biomarkers for the presence and source origin of $\mathrm{TOM}$ - and for $\mathrm{Hg}$ due to their close associations-in sediments. In the two flooded Gabbro and Sandgirt lakes, we observed drastic increases in total mercury concentrations, $\mathrm{T}-[\mathrm{Hg}]$, in sediments, which temporally coincided with the time of reservoir impoundment as assessed by ${ }^{210} \mathrm{~Pb}$ age dating. In the natural Atikonak lake sediments, on the other hand,
\end{abstract}

\author{
R. Teisserenc - M. Lucotte $\cdot$ R. Canuel - M. Moingt \\ Collaborative Mercury Research Network, \\ Institut des Sciences de l'Environnement \\ and GEOTOP, Université du Québec à Montréal, \\ Succ. Centre-ville, C.P. 8888, Montreal, \\ QC H3C 3P8, Canada \\ e-mail: lucotte.marc_michel@uqam.ca \\ R. Canuel \\ e-mail: canuel.rene@uqam.ca
}

M. Moingt

e-mail: matthieumoingt@yahoo.fr
$\mathrm{T}-[\mathrm{Hg}]$ showed no such step-increase but gradually and slowly increased until present. $\mathrm{T}-[\mathrm{Hg}]$ increases in lake sediments after flooding were also associated with a change in the nature of TOM: biomarker signatures changed to typical signatures of TOM from vegetated terrestrial landscape surrounding the lakes, and indicate a change to TOM that was much less degraded and typical of forest soil organic horizons. We conclude that $\mathrm{T}-[\mathrm{Hg}]$ increase in the sediments of the two flooded reservoirs was the result of flooding of surrounding forests, whereby mainly surface organic horizons and upper soil horizons were prone to erosion and subsequent re-sedimentation in the reservoirs. The fact that $\mathrm{T}-[\mathrm{Hg}]$ was still enriched 40 years after reservoir impoundment indicates prolonged response time of lake $\mathrm{Hg}$ and sediment loadings after reservoir impoundments.

Keywords Reservoir $\cdot$ Mercury $\cdot$ Lignin biomarkers $\cdot$ Terrestrial organic matter

Present Address:

R. Teisserenc $(\square)$

Université de Toulouse; INP, UPS, CNRS; EcoLab

(Laboratoire Ecologie Fonctionnelle et Environnement), ENSAT, Avenue de l'Agrobiopole, Auzeville-Tolosane, BP 32607, 31326 Castanet Tolosan Cedex, France e-mail: roman.teisserenc@ensat.fr

D. Obrist

Division of Atmospheric Sciences, Desert Research Institute, 2215 Raggio Parkway, Reno, NV 89512, USA e-mail: daniel.obrist@dri.edu 


\section{Introduction}

The creation of man-made reservoirs results in flooding of large areas of terrestrial ecosystems and can induce major environmental effects. Many studies have addressed these effects, which range from drastic landscape changes to large perturbations in elemental biogeochemical cycles (Kelly et al. 1997; St Louis et al. 2000; Hall et al. 2005). One of the most widely documented changes is the alteration of the mercury $(\mathrm{Hg})$ cycle. The creation of artificial water bodies is generally accompanied by increased levels of total (T$[\mathrm{Hg}])$ and methyl $([\mathrm{MeHg}])$ mercury in the water column, sediments, and biota (St Louis et al. 2004). High $\mathrm{Hg}$ concentrations in fish are of particular concern because they may translate into high $\mathrm{Hg}$ exposure for subsistence or sport fishers. $\mathrm{Hg}$ is considered one of the greatest drawbacks of reservoir-induced changes.

$\mathrm{Hg}$ dynamics in reservoirs have been investigated for more than two decades now (Bodaly et al. 1984), with many investigations ultimately focusing on $\mathrm{Hg}$ contamination in fish (French et al. 1999; Verdon et al. 1991). While almost all studies attribute $\mathrm{Hg}$ increases in reservoirs to a release of $\mathrm{Hg}$ from flooded soils, no study has explicitly tested this hypothesis using biogeochemical tracers. The first specific objective of this study is to confirm this largely used hypothesis using an integrated method that combines conventional analysis of $\mathrm{Hg}$ in sediments with age dating $\left({ }^{210} \mathrm{~Pb}\right)$, and application of biomarker characterization of terrigenous organic matter (TOM).

TOM biomarkers are derived from mild cupric oxide $(\mathrm{CuO})$ oxidation that include lignin derived phenols, tannins, and flavonoid-derived compounds. Formally designated as lignin biomarkers, these compounds are specific markers of TOM because they are directly derived from plants (Hedges and Mann 1979). TOM biomarkers have been successfully used to trace the terrestrial origins of $\mathrm{OM}$ in aquatic ecosystems (Goñi and Hedges 1995; Houel et al. 2006), and studies by our group have shown the use of lignin biomarkers in describing TOM source and quality at the watershed scale (Teisserenc et al. 2010). Recent studies have highlighted the potential use of biomarkers in describing TOM associated with $\mathrm{Hg}$ dynamics (Caron et al. 2008; Teisserenc et al. 2011). It is known that organic matter plays a critical role in sorption of $\mathrm{Hg}$ and in the transfer of $\mathrm{Hg}$ from the terrestrial ecosystem to aquatic environments (Schuster 1991; Kolka et al. 1999). Hg is deposited via dry or wet deposition to vegetation and terrestrial ecosystems where it then strongly sorbs to surface litter and soil horizons (Meili 1991; Grigal 2003; Obrist et al. 2011). These terrestrial stores of $\mathrm{Hg}$ may ultimately leach into aquatic systems (Rencz et al. 2003), and this transfer is often directly associated with the transport of organic carbon in either dissolved or particulate form (Kolka et al. 1999; Ravichandran 2004).

Our second objective is to characterize the role of TOM in the transfer of $\mathrm{Hg}$ to reservoirs, in particular determine how OM characterization in sediments can be used to track and characterize the origin of $\mathrm{Hg}$ in lake sediments. We propose that analysis of TOM in sedimentary deposits in a flooded lake (i.e. incorporated in a reservoir) provide a detailed record of origins of both $\mathrm{T}-[\mathrm{Hg}]$ and $\mathrm{TOM}$ following the impoundment of forest ecosystem. In order to characterize changes in $\mathrm{TOM}-\mathrm{Hg}$ dynamics in flooded reservoirs, we compared sediment records of two recently flooded lakes, Sandgirt and Gabbro, which are part of the Churchill Falls Hydroelectric complex, with that of Atikonak lake, a natural unflooded lake located upstream $(120 \mathrm{~km})$ of these reservoirs. Along the manuscript, flooded lake will refer to these two lakes that have been incorporated in the Churchill Fall Hydroelectric complex. Accumulating zones in reservoir sediments are considered spatially homogeneous, continuously deposited, and unlikely to have been disturbed by wave and currents (Shotbolt et al. 2005). These zones, particularly in flooded lakes, are hence expected to provide detailed temporal records of contaminants and organic matter inputs (Shotbolt et al. 2005). This project is part of the COllaborative MErcury Research Network (COMERN), which has undertaken an ecosystem study of the mercury cycle in this reservoir in order to minimize $\mathrm{Hg}$ exposure of local communities by fish consumption.

\section{Methods}

Study sites

The Churchill Falls Hydroelectric complex is located in central Labrador, Canada (Fig. 1). The bedrock geology in this region is dominated by gneiss and granites that belong to the Precambrian Canadian 
Shield. Sandgirt and Gabbro lakes, which are now included in the Churchill Falls Hydroelectric complex, drain water of the Labrador plateau that lies in the Churchill geological province. Glacial retreat in this central part of Labrador occurred around 6,000 years BP. The climate of central Labrador is continental, with long snowy and severe winters. The annual precipitation is from 900 to $1,100 \mathrm{~mm}$ and is characterized by heavy snow accumulation $(300-400 \mathrm{~cm})$. The annual growing season lasts from 100 to 120 days. The main vegetation is open woodland dominated by black spruce (Picea mariana) and lichen (Cladonia rangiferina). Soil organic horizons are thin and patchy. Atikonak lake, $150 \mathrm{~km}$ to the south of the hydroelectric complex, is located in the eastern part of the Grenville geological province. Its watershed is located at the northern limit of the boreal forest. Black spruce and lichen still dominate the landscape. However, the tree density is higher and organic horizons of soils are thicker. Peatlands dominate the landscape in both areas along with small and shallow lakes.

Built between 1966 and 1974, the Churchill Falls Hydroelectric complex constitutes the second largest series of reservoirs in the world, with a surface area of $6,650 \mathrm{~km}^{2}$. Created by damming the Churchill river and derivation of the Naskapi river, the reservoir is composed of 88 dikes and is divided into three water bodies regulated by three control structures: the Forebay reservoir, the Smallwood reservoir and the Ossokmanuan reservoir. Sandgirt lake is included within the Smallwood reservoir and lake Gabbro within the Ossokmanuan reservoir. 40 and $25 \%$, respectively of the surface of the Smallwood and Ossokmanuan reservoirs are composed of flooded
Fig. 1 Map of sampled sites

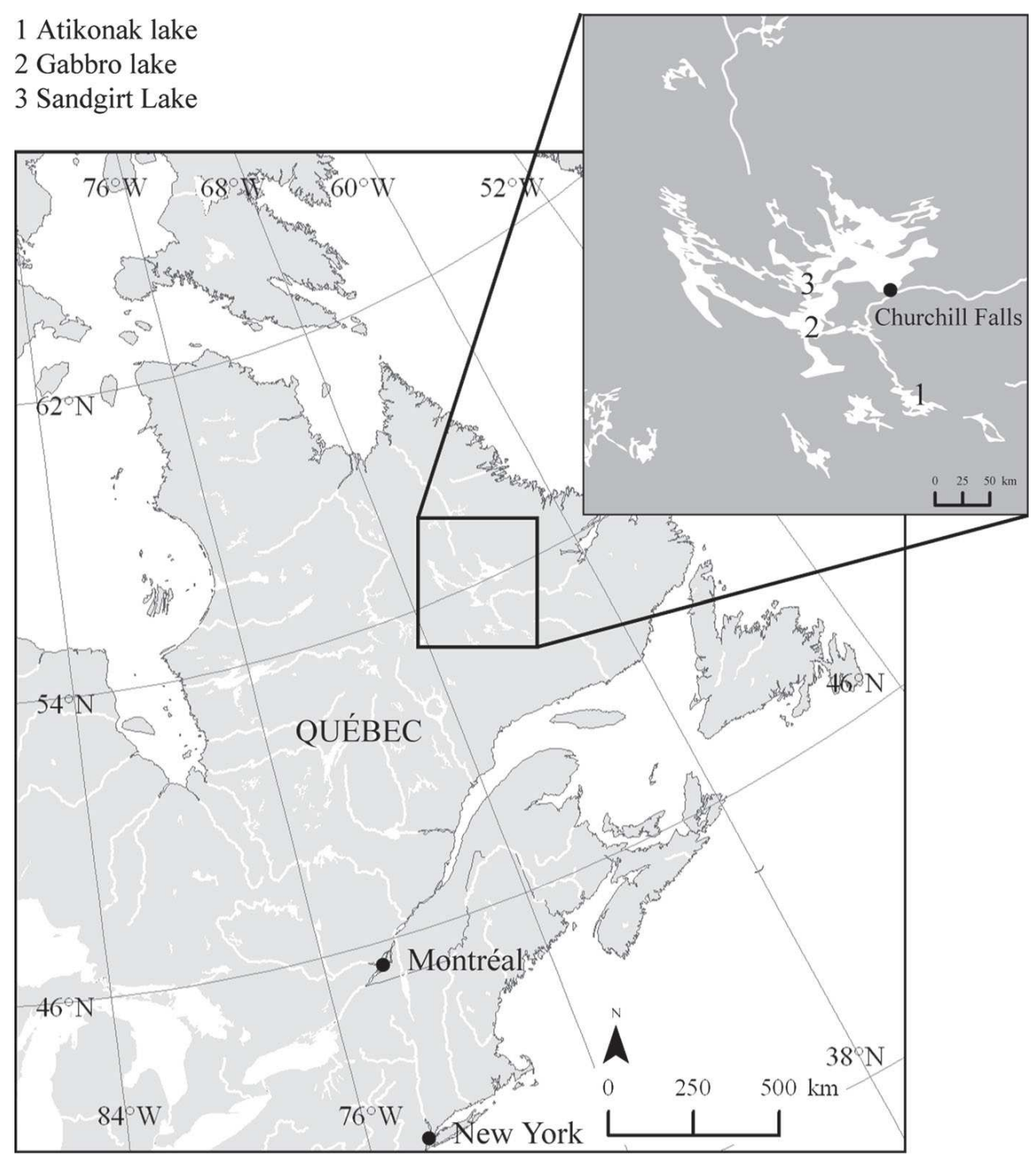


land, which was once forest, peat lands, and barren lands. The drainage area of the complex is now $69,000 \mathrm{~km}^{2}$, including diversions.

\section{Sampling}

Sediment cores were sampled using a pneumatic Mackereth corer at the focal point of each of the three lakes. The focal point represents the deepest point of the accumulating zone and was located via lakes bathymetry. The technique consists of inserting a $1-\mathrm{m}$ long Plexiglas tube (diameter: $10 \mathrm{~cm}$ ) into the sediment using compressed air. This corer offers the advantage of producing very few perturbations at the water-sediment interface. Sediment cores were then sub-sampled in $20 \mathrm{~mL}$ glass vials (pre-heated at $500{ }^{\circ} \mathrm{C}$ for $3 \mathrm{~h}$ and capped with Teflon ${ }^{\circledR}$ liners) in $1-\mathrm{cm}$ sections using a Teflon ${ }^{\circledR}$ spatula. To avoid cross contamination between samples, the sediment contour in contact with the corer was removed. The samples were then freezedried and homogenized manually with an agate mortar grinder prior to analysis. Core lengths were 25, 45, and $50 \mathrm{~cm}$ in Sandgirt, Atikonak, and Gabbro lakes, respectively.

\section{Chemical analysis}

Sediment accumulation rates were determined for the two flooded lakes by alpha spectrometric measurements of ${ }^{210} \mathrm{~Pb}$ via its daughter product ${ }^{210} \mathrm{Po}$ activities following the method initially developed by Flynn (1968). Po isotopes were deposited on a spinning Ag disc (Hamilton and Smith 1986) and activity measured by $\alpha$-spectrometry using ORTEC silicon surface barrier detectors. Analytical reagent blanks were run throughout the analytical procedure. For each core, ${ }^{210} \mathrm{~Pb}$ activity was estimated from the average of values where the asymptotic trend does not show difference in the values within the analytical error. Water contents of each sample were determined in order to correct sediment accumulation rates due to possible compaction of the core during sampling.

Analyses of T-[Hg] were performed by cold vapour atomic fluorescence spectrometry (CVA-FS) following the protocol developed by Bloom and Fitzgerald (1988) and adapted by Pichet et al. (1999). Briefly, a mixture of nitric and hydrochloric acid (16 and $6 \mathrm{~N}$, 10:1 mL) was added to approximately $250 \mathrm{mg}$ of freeze dried, ground sediment sample and heated at $120{ }^{\circ} \mathrm{C}$ for $6 \mathrm{~h}$. The solution was then diluted to $30 \mathrm{~mL}$ volume using NANOpure ${ }^{\circledR}$ water and analyzed by atomic fluorescence. Analyses were carried out in duplicates with a reproducibility of $\pm 5 \%$.

Total carbon and nitrogen analyses used a Carlo Erba (NA-1500) elemental analyzer. Analyses were carried out in duplicates with a reproducibility of $\pm 5 \%$. Molecular TOM biomarker analyses were performed according to the copper oxidation $(\mathrm{CuO})$ method initially developed by Hedges and Ertel (1982) and modified by Goñi and Montgomery (2000). One sample on five was carried in duplicate. Average standard deviation of replicate analysis is below $15 \%$ for the major $\mathrm{CuO}$ oxidation products. A "standard" lake sediment sample SAG05 was also regularly analyzed for comparison with previous study (Louchouarn et al. 1997; Goñi and Montgomery 2000; Houel et al. 2006). In this SAG05 standard, the average variability for all parameters was better than $10 \%$. Briefly, a sediment sample including a minimum of 3-5 mg of organic carbon were oxidized with $\mathrm{CuO}$ in a $2 \mathrm{~mol} \mathrm{~L}^{-1} \mathrm{NaOH}$ solution under exclusion of $\mathrm{O}_{2}$ in an oven at $150{ }^{\circ} \mathrm{C}$ for $180 \mathrm{~min}$ in $3.2 \mathrm{~mL}$ stainless steel mini-bombs (Prime Focus ${ }^{\circledR}$ Inc, Seattle). Once vials were opened, ethyl vanillin $(50 \mu \mathrm{L})$ was added to the solutions as an internal standard. The aqueous solutions were acidified to $\mathrm{pH} 1$ with concentrated $\mathrm{HCl}$ and extracted with ethyl acetate. After evaporation in a centrivap coldtrap, reaction products were dissolved in pyridine and derivatized with bis(trimethylsilyl)-trifluoroacetamide-trimethylchlorosilane (BSTFA-TMCS) to form trimethylsilyl derivatives. Extraction products were then analyzed on a Gas Chromatograph-Mass Spectrometer system (Model 3800-Saturn 2000, Varian) fitted with a fused capillary column (Varian FactorFour VF-1 ms 60 m, $0.32 \mathrm{~mm})$.

We analyzed and quantified 12 TOM biomarker compounds, which are classified in 5 groups: (1) vanillyls $(\mathrm{V})$, including vanillin $(\mathrm{Vl})$, acetovanillon $(\mathrm{Vn})$, and vanillic acid (Vd); (2) syringyls (S), including syringin $(\mathrm{Sl})$, acetosyringone $(\mathrm{Sn})$, and syringic acid ( $\mathrm{Sd}$ ); (3) cinnamyls (C), including coumaric acid, (p-Cd) and ferulic acid (Fd); (4) parahydroxyphenols $(\mathrm{P})$, including $\mathrm{p}$-hydroxybenzaldehyde (Pl), p-hydroxyacetophenone (Pn), and p-hydroxybenzoic acid (Pd); and (5) 3,5-dihydroxybenzoic acid (3,5Bd). 


\section{Results}

Radiometric measurements in core sediments

In surface sediments, we measured ${ }^{210} \mathrm{~Pb}$ activities of 63, 36 and $47 \mathrm{dpm} \mathrm{g}^{-1}$ for Atikonak, Gabbro, and Sandgirt lakes, respectively (Fig. 2a-c). Chronology was established using unsupported ${ }^{210} \mathrm{~Pb}$ data of the core $\left({ }^{210} \mathrm{~Pb}_{\mathrm{ex}} ; \mathrm{T}_{1 / 2}=22.3 \mathrm{y}\right)$, and mass depth was used rather than true depth to take compaction effects into account (Abril 2003). Sediment accumulation rates were estimated using the slope of the relationship between mass depth $\left(\mathrm{g} \mathrm{cm}^{-2}\right)$, the natural logarithm of ${ }^{210} \mathrm{~Pb}_{\mathrm{ex}}$ and the ${ }^{210} \mathrm{~Pb}$ decay constant. In Gabbro lake, because of bioturbation in the first centimetres of the core, the first two sections were not been taken into account for the estimation of the sediment accumulation rate. Moreover, because of an apparent change in the sedimentation rate of this lake, non-linear profiles have been divided into linear profiles assuming constant sedimentation for each of these segments (Appleby and Oldfield 1990; Houel et al. 2006). Because of high correlation coefficients within each segment $\left(\mathrm{R}^{2}=0.90-0.99\right.$; Fig. 2e) a minimal mixing and a constancy of accumulation rate can be assumed during the period of each segment. Estimated sediments accumulation rates are $0.02 \mathrm{~g} \mathrm{~cm}^{-2}$ year $^{-1}$ in Atikonak lake, $0.06 \mathrm{~g} \mathrm{~cm}^{-2}$ year $^{-1}$ in Sandgirt lake; 0.03 and $0.07 \mathrm{~g} \mathrm{~cm}^{-2}$ year $^{-1}$ in Gabbro lake before and after impoundment, respectively. Based on these results and using the specific porosity of each layer, we estimated the age of sediments for each core (Fig. $2 g_{-}$ i). Those chronologies situate the impoundment ( $\sim 40$ years; 1966-1974) around a depth of $\sim 5$ and $\sim 6 \mathrm{~cm}$ for Sandgirt and Gabbro lakes, respectively (Fig. 2h, i).

\section{Mercury}

Sedimentary profiles for $\mathrm{T}-[\mathrm{Hg}]$ show a gradual increase with depth in the unflooded Atikonak lake (Fig. 3). $\mathrm{T}-[\mathrm{Hg}]$ baseline of this sediment core ranges between 80 to $100 \mathrm{ng} \mathrm{g}^{-1}$, and gradually increases to $220 \mathrm{ng} \mathrm{g}^{-1}$ in recent sediments. An inflexion of $\mathrm{T}-[\mathrm{Hg}]$ occurs at a depth of about $20 \mathrm{~cm}$. Depth distribution patterns of the two flooded lakes show distinctly different patterns to that of Atikonak lake, both showing sharp and sudden increases in $\mathrm{T}-[\mathrm{Hg}]$ in recent sediments (i.e. upper $6-7 \mathrm{~cm}$ ). Sandgirt and Gabbro lakes show $\mathrm{T}-[\mathrm{Hg}]$ baselines around 20 and $90 \mathrm{ng} \mathrm{g}^{-1}$, respectively, with recent $\mathrm{T}-[\mathrm{Hg}]$ values increased by a factor of 7.4 and 1.6, respectively. We also observed a noticeable increase in $\mathrm{T}-[\mathrm{Hg}]$ at about $18 \mathrm{~cm}$ depth in Gabbro lake, a peak that then gradually returned to the baseline concentration in overlying depths.

\section{Terrestrial organic matter levels}

Terrestrial organic matter biomarkers in sediments are quantified as $\lambda 8$, which signifies the carbon-normalized total yield [in mg per $100 \mathrm{mg}$ organic carbon (mg $\left.100 \mathrm{mg} \mathrm{OC}^{-1}\right)$ ] of the eight lignin-derived phenols (vanillin, acetovanillone, vanillic acid, syringealdehyde, acetosyringone, syringic acid, p-coumaric, and ferulic acids. A second TOM measure are $\Sigma 8$, which expresses the same biomarkers as total yield normalized to total dry mass of samples (in $\mathrm{mg}$

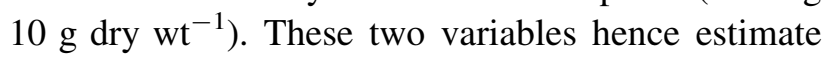
the relative amount of lignin-products-all of which are directly derived from plants-in sedimentary organic matter thereby indicating the importance of TOM in samples (Houel et al. 2006). In Atikonak lake, $\lambda 8$ and $\Sigma 8$ are stable along the core, indicating no major change in the types of TOM inputs to sediments over time (Fig. 4). $\lambda 8$ ranged between 0.5 and $1.0 \mathrm{mg}$ $100 \mathrm{mg} \mathrm{OC}^{-1}$, which is similar to values observed in previous studies in lake sediments at similar latitudes (Hu et al. 1999; Pempkowiak et al. 2006; Houel et al. 2006). $\Sigma 8$ values stayed closed to values of $5 \mathrm{mg}$ $10 \mathrm{~g}^{\mathrm{dry}} \mathrm{wt}^{-1}$, which is lower than values observed by Pempkowiak et al. (2006), but in similar range to data reported by Houel et al. (2006).

$\lambda 8$ and $\Sigma 8$ values at the two flooded sites showed a sharp increase in recently deposited sediments at a depth of about $7 \mathrm{~cm}$ (Fig. 4). The increase of these lignin biomarkers is most drastic in sediments of Sandgirt lake where baseline values for $\lambda 8$ and $\Sigma 8$ of $0.1 \mathrm{mg} 100 \mathrm{mg} \mathrm{OC}^{-1}$ and $0.02 \mathrm{mg} 10 \mathrm{~g} \mathrm{dry} \mathrm{wt}^{-1}$, respectively, increase up to $2 \mathrm{mg} 100 \mathrm{mg} \mathrm{OC}^{-1}$ and $30 \mathrm{mg} 10 \mathrm{~g} \mathrm{dry} \mathrm{wt}^{-1}$. In Gabbro lake, $\lambda 8$ values increased from 0.5 to $2.5 \mathrm{mg} 100 \mathrm{mg} \mathrm{OC}^{-1}$, and $\Sigma 8$ values increased from 2 to $20 \mathrm{mg} 10 \mathrm{~g}$ dry $\mathrm{wt}^{-1}$. In Gabbro lake, we also observed an increase of $\lambda 8$ and $\Sigma 8$ at about centimeter 18 . 

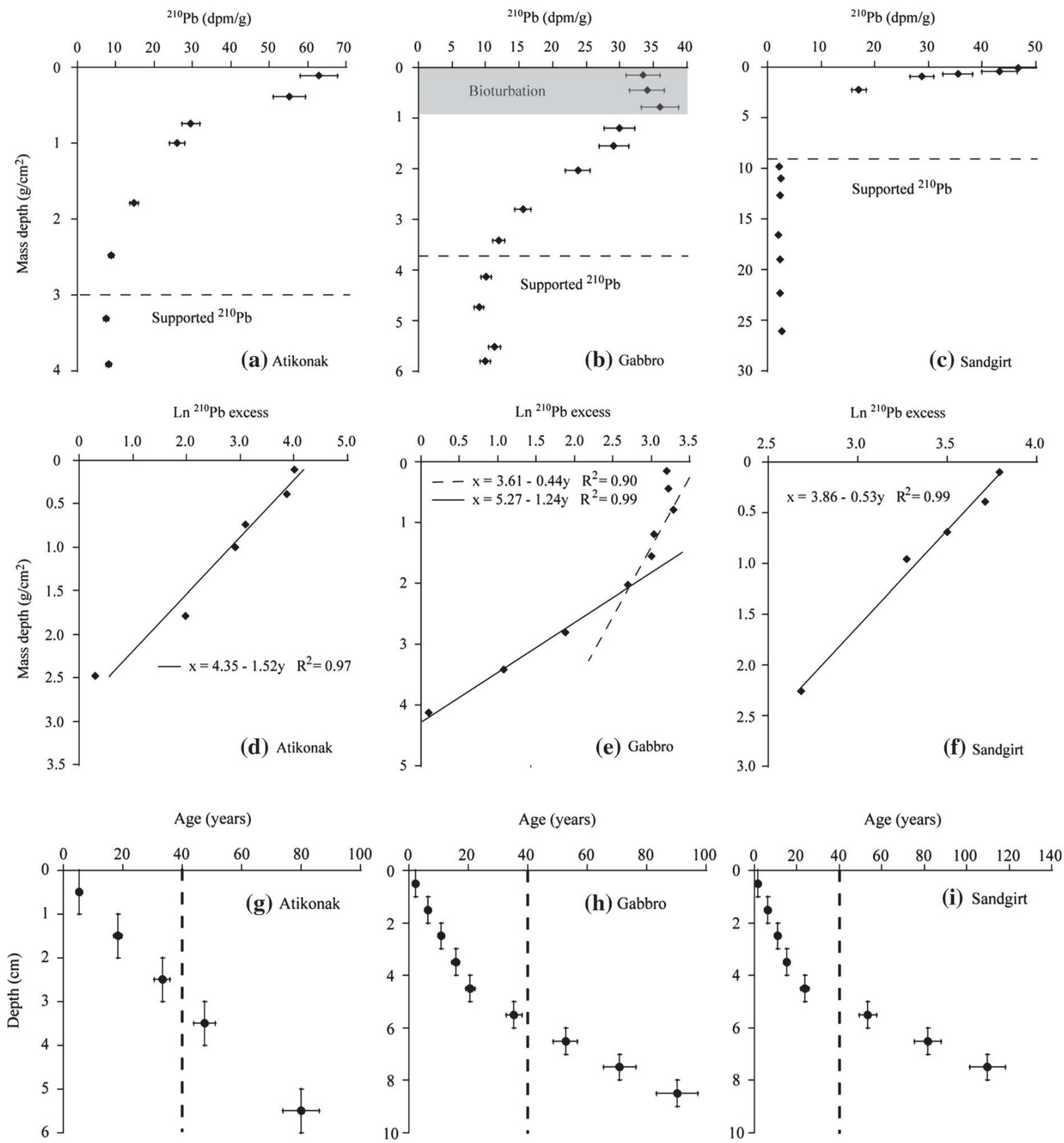

Fig. 2 Total ${ }^{210} \mathrm{~Pb}$ activity $\left(\mathrm{dpm} \mathrm{g}^{-1}\right) \quad(\mathbf{a}-\mathbf{c})$ and natural logarithm of the excess of ${ }^{210} \mathrm{~Pb}$ versus mass depth $\left(\mathrm{g} \mathrm{cm}^{-2}\right)$ $(\mathbf{d}-\mathbf{f})$ in Atikonak Lake used as reference lake and in the Gabbro,

\section{TOM composition}

Lignin-derived phenols can be further separated by composition to build ratios of biomarkers to be used to distinguish between origin and sources of TOM. Ratios of $\mathrm{S}: \mathrm{V}, \mathrm{C}: \mathrm{V}$, and $\mathrm{P}:(\mathrm{V}+\mathrm{S})$ in the sediments and Sandgirt flooded lakes. g-i Age (years) versus depth $(\mathrm{cm})$ of the sediment cores from Atikonak Lake and the Gabbro and Sandgirt flooded lakes

of Atikonak lake remain relatively stable along the core (Figs. 5, 6). S:V ratios are around 0.4, and C:V ratios range between 1.0 and 1.5. $\mathrm{P}:(\mathrm{V}+\mathrm{S})$ in sediment of Atikonak lake, with an average value around 1.3. In the flooded Gabbro lake, ratios of S:V, $\mathrm{C}: \mathrm{V}$, and $\mathrm{P}:(\mathrm{V}+\mathrm{S})$ are much more variable, and all 


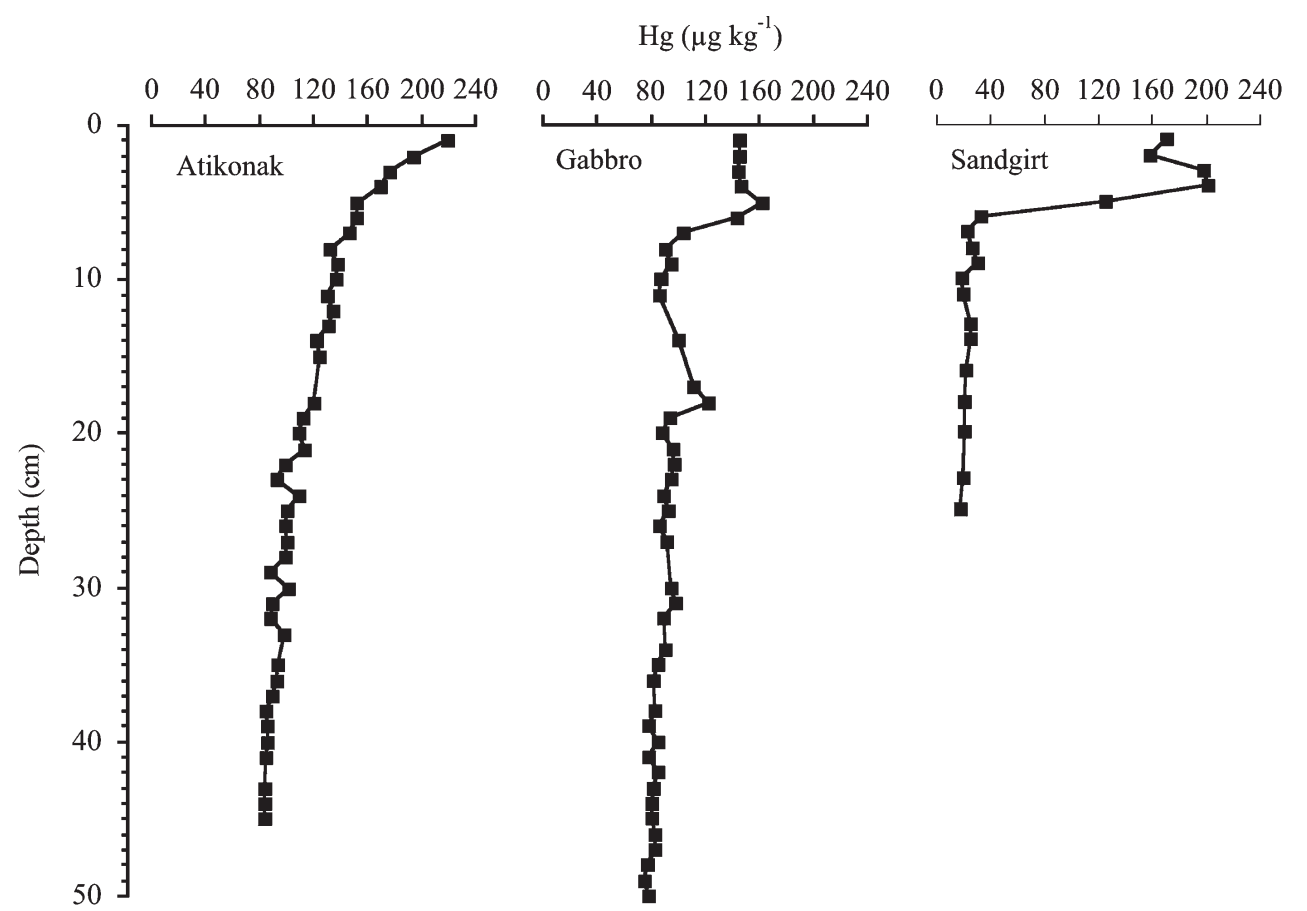

Fig. 3 Sedimentary profiles of mercury $(\mathrm{Hg})\left(\mu \mathrm{g} \mathrm{kg}{ }^{-1}\right)$ of Atikonak (unflooded), Gabbro and Sandgirt (flooded) lakes

Fig. 4 Sedimentary profiles of carbon- and mass-normalized yields of the sum of lignin-derived cinnamyl, vanillyl and syringyl oxidation byproducts: $\lambda 8(\mathrm{mg} 100 \mathrm{mg}$ $\left.\mathrm{OC}^{-1}\right)$ and $\Sigma 8(\mathrm{mg}$

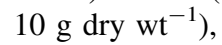
respectively of Atikonak (unflooded), Gabbro and Sandgirt (flooded) lakes

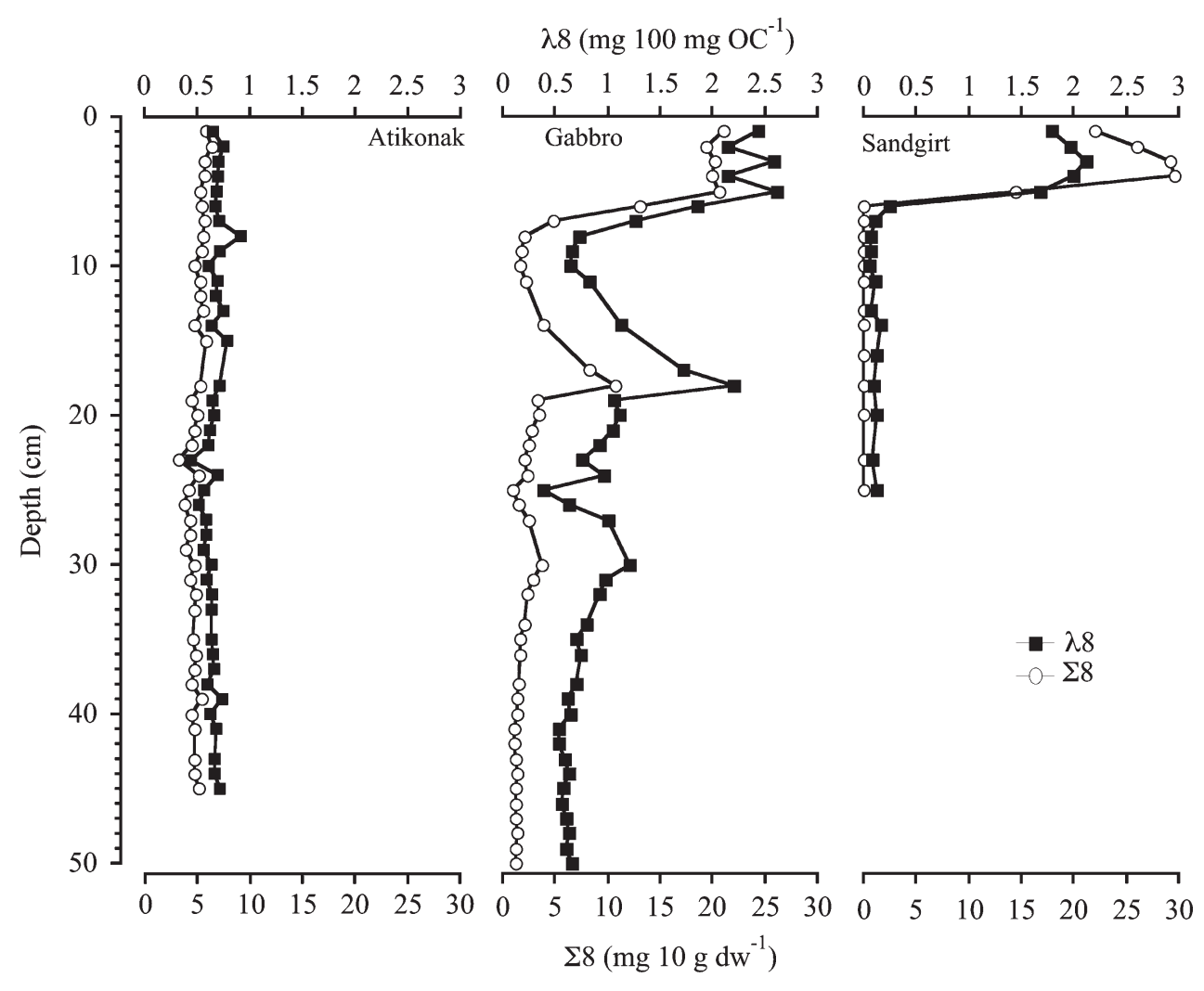

show strong declines in ratios to lowest values at the top of the core (Figs. 5, 6). These variations in ratios are mainly due to changes in the concentration of vanillyl phenols $(\Sigma \mathrm{V})$, which sharply increases- similar to $\lambda 8$ and $\Sigma 8$-in recent sediments. We also observed an important increase of syringyl phenols $(\Sigma S)$, although the increase was not as pronounced as that of $\Sigma \mathrm{V}$. No change was observed in cinnamyl 
phenols $(\Sigma \mathrm{C})$ (Fig. 7). For Sandgirt lake, C:V ratios decreased in the upper sediments, although here the decrease is related to a proportionally higher increase of vanillyl phenols than cinnamyl phenols (Figs. 5, 7). In contrast to Gabbro lake, $\mathrm{S}: \mathrm{V}$ ratios increase in recent sediment, which is mainly due to the fact that syringyl phenols $(\Sigma S)$ were below detection limits at the bottom of the core (i.e., $\mathrm{S}: \mathrm{V}$ ratio of null) but showed detectable levels in upper sediments (Figs. 5, 7).

Ratios of $3,5 \mathrm{Bd}: \mathrm{V}$ ratios at Atikonak lake are generally near a value of 1.0, although between depths 28 and $31 \mathrm{~cm}$ the values increase to about 1.50 (Fig. 6). In the two flooded lakes, we observed a common pattern for 3,5Bd: $\mathrm{V}$ ratios: ratios are rather variable at the bottom of the cores, but constant and low above centimeter 10 and 5, respectively (Fig. 6). For these variations, it is mainly vanillyl phenol contents of samples that drive these variations, although 3,5Bd also show significant increases in the top of cores.

Sedimentary profiles of atomic carbon to nitrogen (C:N) ratio and of acid to aldehyde ratio for vanillyl (Ad:Al)V and syringyl (Ad:Al)S phenols are presented as supplementary material.

\section{Discussion}

Identification of the flooding event in sediment record

Sedimentary records of flooded lakes hold information on both pre- and post-flooding events. Usually, flooding events modify organic matter dynamics in sediments resulting in sharp increases of TOM in recent sediments (Louchouarn et al. 1993). In this study, the sum of lignin-derived phenols $(\lambda 8$ and $\Sigma 8$ ) show drastic changes in organic matter dynamics at sediment core depths of $7 \mathrm{~cm}$ and $6 \mathrm{~cm}$ in Gabbro and Sandgirt lakes, respectively. To confirm that these changes in patterns in the sediment cores corresponded to the timing of flooding, we performed ${ }^{210} \mathrm{~Pb}$ dating of the sediment cores. The results of age dating confirmed that the time of flooding 40 years ago corresponds to sediment core depths of about $5 \mathrm{~cm}$ and $6 \mathrm{~cm}$ depth for Sandgirt and Gabbro lakes, respectively. These data are hence consistent with the depth where we observed strong increases in $\mathrm{T}-[\mathrm{Hg}]$ (Fig. 3), strong increases in TOM loadings (Fig. 4), and substantial changes in ratios of individual lignin-derived phenol groups (Figs. 5, 6, 7).
Fig. 5 Sedimentary profiles of lignin source ratios of Atikonak (unflooded), Gabbro and Sandgirt (flooded) lakes. $\mathrm{S}: \mathrm{V}$, ratio syringyl to vanillyl phenols; $\mathrm{C}: \mathrm{V}$, ratio of cinnamyl to vanillyl phenols

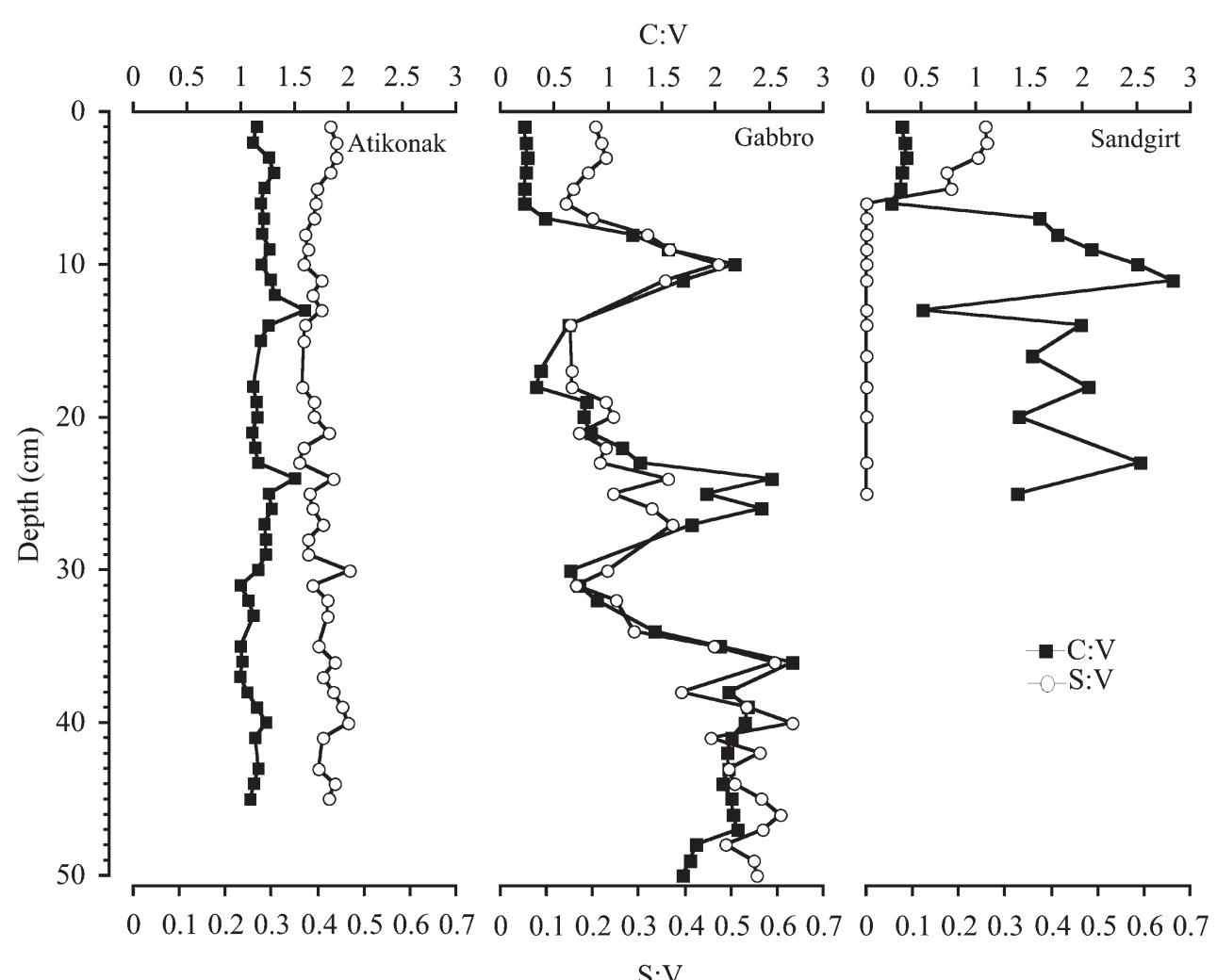

$\mathrm{S}: \mathrm{V}$ 
Fig. 6 Sedimentary profiles of lignin and organic matter degradation state indicators of Atikonak (unflooded), Gabbro and Sandgirt (flooded) lakes. $\mathrm{P}:(\mathrm{V}+\mathrm{S})$, ratio p-hydroxyl phenols to the sum of vanillyl and syringyl phenols. 3,5Bd: $\mathrm{V}$, ratio of 3,5-dihydroxybenzoic acid over vanillyl phenols

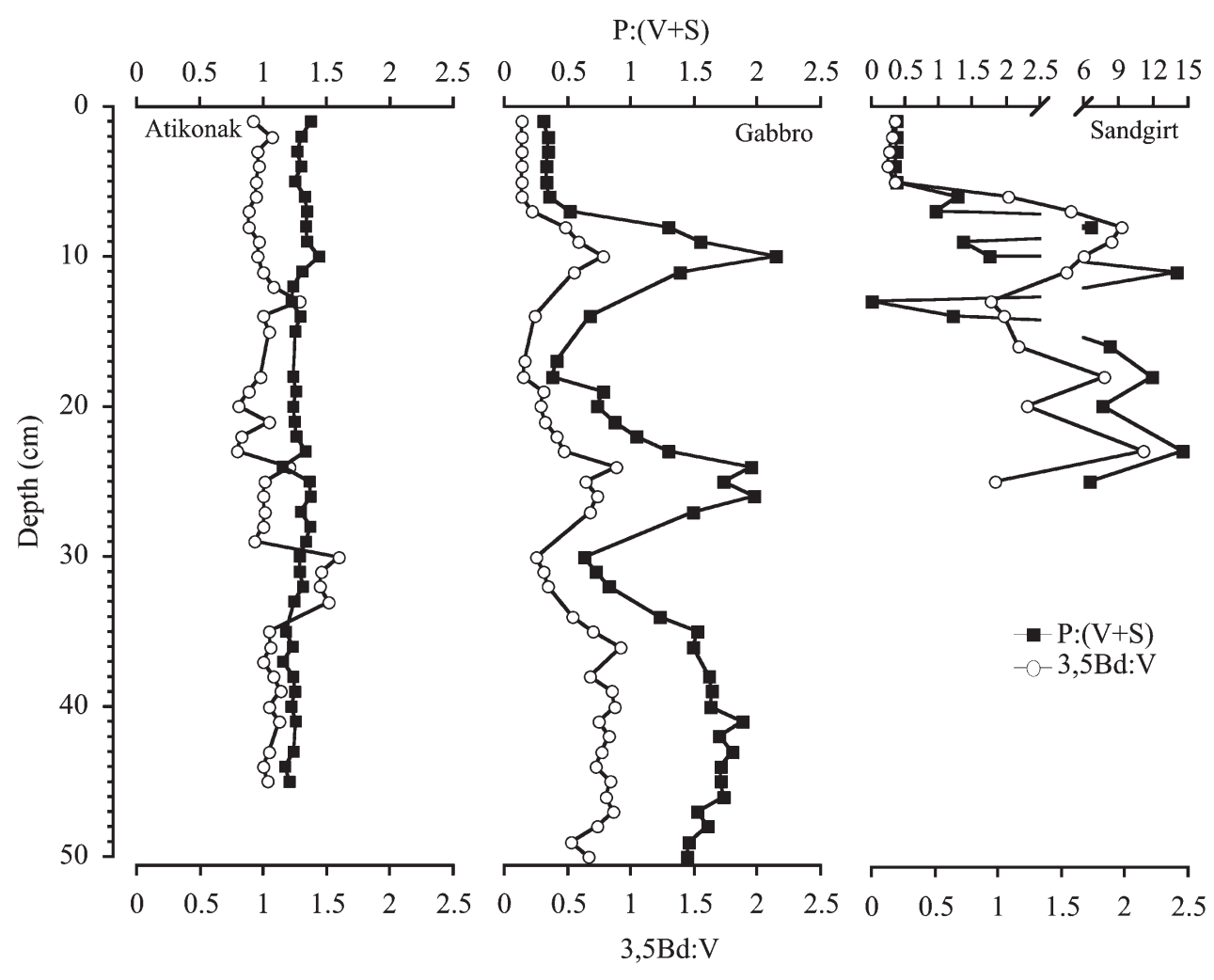

Fig. 7 Sedimentary profiles of sum of vanillyl $(\Sigma \mathrm{V})$, syringyl $(\Sigma \mathrm{S})$, and cinnamyl $(\Sigma \mathrm{C})$ phenols $(\mathrm{mg}$ $100 \mathrm{mg} \mathrm{OC}^{-1}$ ) of Atikonak (unflooded), Gabbro and Sandgirt (flooded) lakes

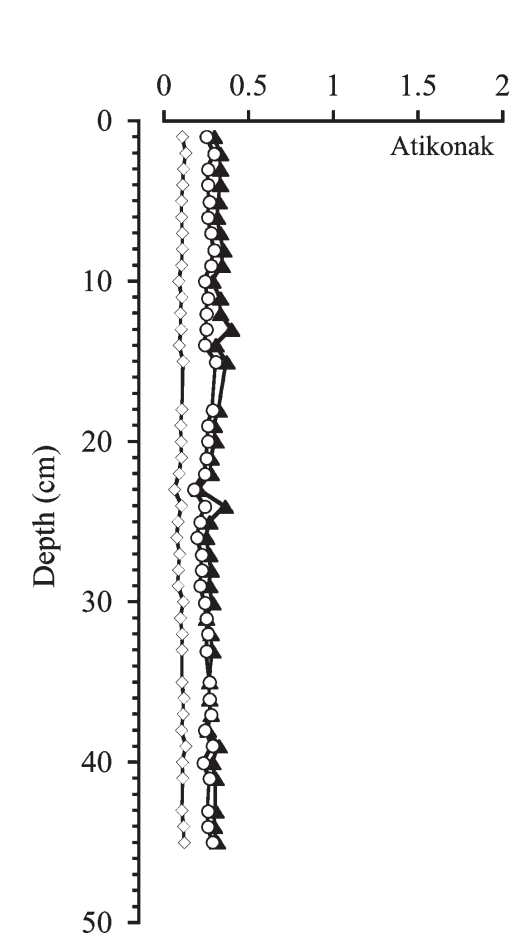

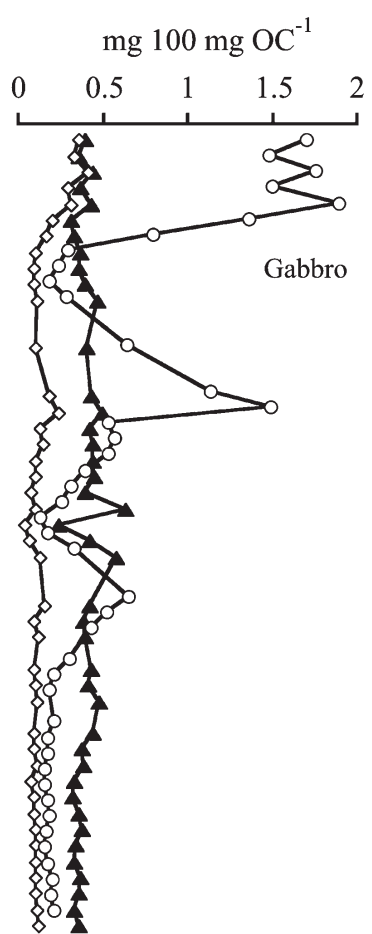

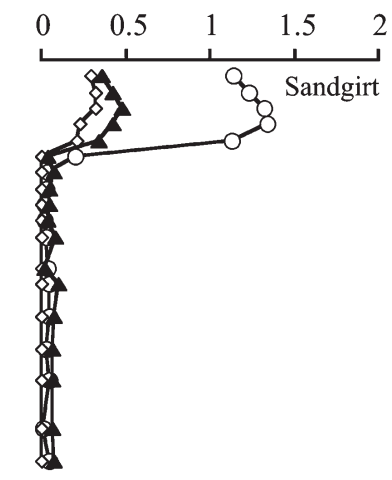

Link between levels of lignin derived phenols and mercury

$\mathrm{T}-[\mathrm{Hg}]$ in recent sediments of all three lakes under study are much higher than baseline levels observed in deep sediments. Increases of $\mathrm{T}-[\mathrm{Hg}]$ in boreal lake sediments may be explained by three principal factors: (i) mercury remobilisation from bottom sediments has been proposed as a potential reason by Rasmussen (1994), but Fitzgerald et al. (1998) demonstrated that 
this phenomenon is limited and cannot explain $\mathrm{Hg}$ enrichments generally observed in recent lake sediments of the northern hemisphere; (ii) watershed perturbations such as forest fires, landslides, and forest logging, play a key role in the $\mathrm{Hg}$ cycle in boreal catchments (Munthe and Hultberg 2004; Garcia and Carignan 2005), and such disturbances are usually recorded in sedimentary profiles (Caldwell et al. 2000), although mostly at local or regional scales; (iii) for unperturbed watersheds, a broad scientific consensus attributes recent sedimentary $\mathrm{Hg}$ enrichments to long-range atmospheric transport and deposition of anthropogenic $\mathrm{Hg}$ emissions to even remote watersheds where it is ultimately transferred to lakes (Fitzgerald et al. 1998). The sediment profile of $\mathrm{T}-[\mathrm{Hg}]$ in Atikonak lake, which has not been affected by damming and flooding, shows the classical profile of anthropogenic $\mathrm{Hg}$ enrichment observed since the beginning of the industrial era (Lucotte et al. 1995). Increases in $\mathrm{T}-[\mathrm{Hg}]$ started at centimeter 20 , and the enrichment factor between recent sediments and preindustrial baseline level is 1.5 , which is within the range of values observed in lake sediments from the James Bay (Québec, Canada; Lucotte et al. 1995). Results from lignin biomarker profiles in Atikonak lake confirm that increases of $\mathrm{T}-[\mathrm{Hg}]$ cannot be attributed to particular watershed perturbations as TOM levels and biomarker patterns remained very constant in time. The relative amount of terrigenous material in sediments is also comparable to those reported for similar undisturbed lakes (Hu et al. 1999; Houel et al. 2006).

In the two flooded Gabbro and Sandgirt lakes, $\mathrm{T}-[\mathrm{Hg}]$ increased abruptly in recent sediments from a baseline in older, deeper depths, and these increases occurred at depths of 8 and $6 \mathrm{~cm}$, respectively. ${ }^{210} \mathrm{~Pb}$ analysis support that these $\mathrm{T}-[\mathrm{Hg}]$ increases are associated with the timing of flooding. In addition, corresponding increases in TOM loads, $\lambda 8$ and $\Sigma 8$, support this notion. Flooding hence caused important inputs of new terrigenous organic matter into lake sediments which show the signature of the surrounding terrestrial ecosystems. Our results also indicate that TOM plays a key role controlling $\mathrm{Hg}$ inputs to the lakes, a notion that has been shown in many previous studies (Kolka et al. 1999; Teisserenc et al. 2011). Clearly, increased loads of TOM and T-[Hg] still occurred after almost 40 years of flooding (1970 to present), indicating prolonged effects of flooding on sediment TOM and $\mathrm{Hg}$ loadings. Baseline values of TOM ( $\lambda 8$ and $\Sigma 8$ ) also provide insight about the states of the lakes before flooding: Gabbro lake showed levels of $\lambda 8$ and $\Sigma 8$ similar to those of Atikonak lake, likely because both lakes belong to the same Atikonak River drainage basin. Sandgirt lake is mainly drained by the Ashuanipi River, and showed much lower TOM inputs before flooding, and several lignin-derived phenols were below detection. This pattern was accompanied by correspondingly low $\mathrm{T}-[\mathrm{Hg}]$, further evidence of a close association between TOM and $\mathrm{T}-[\mathrm{Hg}]$ loading. We attribute the low TOM and T- $[\mathrm{Hg}]$ levels in Sandgirt to the fact that this lake was surrounded by a series of small, interconnected lakes and barrens, with little developed forests. Sandgirt lake was also a particularly shallow lake before flooding with a maximum depth of only $6 \mathrm{~m}$ (Duthie and Ostrofsky 1974), and baseline sediments of that core were primarily composed of silt and grey clay.

The increase in TOM was much more important in Sandgirt lake than in Gabbro lake upon flooding, which is likely linked to the extent of the flooded area. Gabbro lake is now included within the Ossokmanuan reservoir with a large area of $950 \mathrm{~km}^{2}$ at maximum water level, whereas Sandgirt lake is part of the smaller Smallwood Reservoir of $56,000 \mathrm{~km}^{2}$. In addition, the terrestrial compartment that was flooded differs between the two lakes: only $25 \%$ of the flooded area of the Ossokmamuan Reservoir was composed of upland forests and muskeg, compared with $40 \%$ in the Smallwood Reservoir (Duthie and Ostrofsky 1974). The profiles of $\lambda 8$ and $\Sigma 8$ for Gabbro lake also indicated a major perturbation of the watershed several years before flooding, an event that modified ecosystem dynamics for some time before TOM inputs returned to baseline levels. The same perturbation caused a temporary enhancement of $\mathrm{T}-[\mathrm{Hg}]$. Such simultaneous increases of TOM and $\mathrm{Hg}$ in sediment have been related to severe forest fires (e.g., Nelson et al. 2007), which induce increased soil leaching and release of organic matter and associated contaminants (Caldwell et al. 2000), although we have no historic records of wildfire history of this area.

Using TOM as biomarkers in lake sediments

TOM origin can be determined according to ratios of various biomarker groups. (i) Ratios of syringyl to vanillyl phenols $(\mathrm{S}: \mathrm{V})$ have been used to distinguish 
between angiosperm and gymnosperm plants because only angiosperm plants produce syringyl phenols (syringe aldehyde, aceto syringone, syringic acid) (Hedges and Mann 1979). (ii) Ratios of cinnamyl to vanillyl phenols $(\mathrm{C}: \mathrm{V})$ are commonly used as indicator of source tissues because non-woody plants and leaves produce much more cinnamyl phenols (ferulic acid and p-coumaric acid) than woody parts of plants. Meanwhile, vanillyl phenols are ubiquitous in all terrestrial plants. (iii) Ratios of $\mathrm{P}:(\mathrm{V}+\mathrm{S})$ are used as indicators of the state of degradation of terrigenous organic matter. Pedogenetic demethylation leads to selective loss of methoxylated phenol groups of vanillyl and syringyl phenols, while p-hydroxy phenols are not affected by demethylation. P: $(\mathrm{V}+\mathrm{S})$ ratios hence increase with higher states of TOM degradation (Dittmar and Lara 2001). (iv) Finally, $3,5 \mathrm{Bd}$ is a common $\mathrm{CuO}$ oxidation product found in samples from sediment and soils, but not from fresh vascular plant tissues (Ugolini et al. 1981). It has been suggested that this compound is a product of pedogenesis and is directly linked to lignin degradation (Houel et al. 2006; Teisserenc et al. 2010). As a result, in terrestrial and freshwater ecosystems presence of $3,5 \mathrm{Bd}$ biomarkers have been proposed as an indicator of soil organic matter origin (Prahl et al. 1994). The likely precursors of this phenolic product are tannins and other flavonoids (Goñi and Hedges 1995), and because tannin-like materials tend to accumulate within decaying cells a relative increase of $3,5 \mathrm{Bd}$ in mineral horizons of soils may reflect extent of degradation and humification of fresh vascular plant tissues (Houel et al. 2006; Teisserenc et al. 2010).

TOM biomarker patterns remained relatively constant in the sediments of Atikonak lake: for example, $\mathrm{S}: \mathrm{V}$ and $\mathrm{C}: \mathrm{V}$ showed no clear trends along the core, and we hence conclude that this lake received TOM inputs from a relatively unaltered plant composition with no major changes that occurred in its watershed. $\mathrm{S}: \mathrm{V}$ ratios were relatively high for a northern coniferdominated ecosystem dominated by conifers given that only angiosperm plants should produce syringyl monomers (Hedges and Mann 1979). However, we previously found that spruce forests also may produce significant amounts of syringyls monomers (Teisserenc 2009), and leaching and sorption processes in soils may influence $S: V$ and $C: V$ ratios (Hernes et al. 2007). $\mathrm{C}: \mathrm{V}$ ratios measured in the sediments were much higher than those found in boreal forest soils
(Teisserenc 2009), although $\mathrm{Hu}$ et al. (1999) found similar ratios in lake sediments, which they linked to pollen produced by $P$. mariana, the dominant tree species in the region. High $\mathrm{P}:(\mathrm{V}+\mathrm{S})$ and $3,5 \mathrm{Bd}: \mathrm{V}$ ratios in Atikonak lake sediments indicate that TOM is highly degraded and has undergone major humification processes in soils before entering the lake sediments as signatures were similar to inorganic horizons in spruce soils. Such high values are usually associated with low mean slope of watersheds causing slow erosion rates and high residence times of TOM (Teisserenc et al. 2010).

In Gabbro lake, $\mathrm{S}: \mathrm{V}$ and $\mathrm{C}: \mathrm{V}$ ratios in the sediment profile were highly driven by changes in vanillyl phenols content. Following the impoundment, total yield of vanillyl phenols increased proportionally more than that of the cinnamyl and syringyl phenol families, decreasing both $\mathrm{S}: \mathrm{V}$ and $\mathrm{C}: \mathrm{V}$ ratios. The stronger increase of vanillyl phenols compared to cinnamyl and syringyl phenols may be explained by the flooding of vast areas of forest and soil, as cinnamyl and syringyl phenols are specific to certain classes of plants while vanillyl is ubiquitous in terrestrial plants (Hedges and Mann 1979). While $\mathrm{C}: \mathrm{V}$ patterns at Sandgirt lake showed similar behavior as in Gabbro, this lake showed an absence (i.e., below detection) of syringyl phenols before flooding (a ratio of 0 ). Increases in syringyl phenols after flooding then caused $\mathrm{S}: \mathrm{V}$ ratios to be detectable, but they remained low, which is a common characteristic of coniferous boreal forest soils (Teisserenc 2009). Large variability in $\mathrm{C}: \mathrm{V}$ ratios prior to flooding in both lakes is due to certain compounds being below detection limits at certain core depths, thereby distorting the ratios.

Although $\mathrm{P}:(\mathrm{V}+\mathrm{S})$ and 3,5Bd:V ratios were also variable due to variability in vanillyl phenols, they showed simultaneous decreases in both lakes after flooding, suggesting that TOM inputs were less degraded following flooding. This is also supported by the $(\mathrm{Ad}: \mathrm{Al}) \mathrm{V}$ and $(\mathrm{Ad}: \mathrm{Al}) \mathrm{S}$ ratios presented as supplementary material. We propose that substantial mobilization of organic carbon, particularly from surface soil layers, explain the drop in these ratios. We tested this hypothesis using a mixing model proposed by Houel et al. (2006). This mixing model is based on mass-normalized yields of the different $\mathrm{CuO}$ oxidation parameters in two distinct end-members, namely that originating from surface organic spruce stand soil horizons and from deep mineral soil 
horizons from James Bay (Teisserenc 2009). We tested such a model using $3,5 \mathrm{Bd}: \mathrm{V}$ ratios versus carbon-normalized lignin yields $(\lambda 6)$ according to the mixing equation:

$$
\left(\frac{\mathrm{A}}{\mathrm{B}}\right)_{\text {sed }}=\frac{\left(A_{o} \times F_{o}\right)+\left[A_{i} \times\left(1-F_{o}\right)\right]}{\left(B_{o} \times F_{o}\right)+\left[B_{i} \times\left(1-F_{o}\right)\right]}
$$

where A represents the mass-normalized yields for the parameter in the numerator of the ratio $(3,5 \mathrm{Bd}, \mathrm{P}$, and 26); $\mathrm{B}$ represents the mass-normalized yields for the parameter in the denominator $(\mathrm{V},[\mathrm{V}+\mathrm{S}]$, and $\mathrm{OC}$, respectively); $F_{o}$ is the fraction of organic matter derived from surface soil litter in the sedimentary mixture; and the subscripts represent the massnormalized yields observed for the different parameters within sediment intervals (sed), deep soil mineral horizons (i), and surface organic-rich soil litter (o). All mass-normalized yields of the different $\mathrm{CuO}$-derived parameters used in this model are presented in Table 1. Mixing model and observational data fit best when recent sediment in Gabbro and Sandgirt lakes receive input from 3,5Bd:V signatures typical of soil surface horizons (Fig. 8). Highest T-[Hg] are generally observed in organic surface horizons and in top soils of forest soils (Grigal 2003; Friedli et al. 2007; Obrist et al. 2011) due to strong sorption of atmospheric $\mathrm{Hg}$ depositions to these upper, carbon-rich surface pools (Harris et al. 2007; Graydon et al. 2009; Pokharel and Obrist 2011). The results of our biomarker study suggest that it is these $\mathrm{Hg}$-enriched surface pools that contribute most strongly to loadings and enrichment of $\mathrm{T}-[\mathrm{Hg}]$ in reservoir sediments after flooding.

Finally, profiles showing continued high TOM and $\mathrm{T}-[\mathrm{Hg}]$ loadings since flooding (1968-1974) and continued alterations of all biomarker signatures into most recent sediments in Gabbro and Sandgirt lakes suggest that flooded soils continued to be major sources of mercury and organic matter to sediments of these lakes more than 40 years after impoundment.

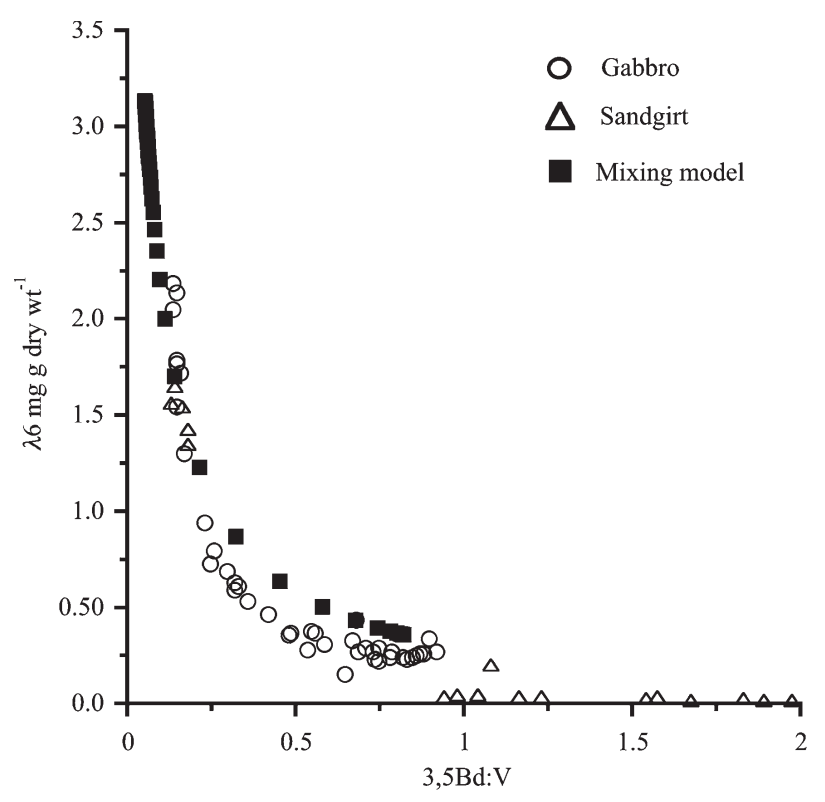

Fig. 8 Measured biomarkers signatures in Gabbro and Sandgirt sediments and comparison to theoretical values based on a mixing model between surface litter and deep mineral SOM end-members. Box represent post-flooding sediments of the two flooded lakes (i.e. 7 and $6 \mathrm{~cm}$ for Gabbro and Sandgirt, respectively)

Previous studies have shown that remobilization of flooded soil organic matter and mercury were limited to the first years after perturbation (Louchouarn et al. 1993; Grondin et al. 1995; Houel et al. 2006), mainly because remobilization was limited to drawdown zones and area of shallow waters (wave influence). The Churchill Falls Hydroelectric complex is characterized by low mean slopes and shallow reservoir depths (about $4 \mathrm{~m}$ drawdown in the Smallwood Reservoir and $3.5 \mathrm{~m}$ in the Ossokmanuan Reservoir; Duthie and Ostrofsky 1974). These characteristics may be the reasons that large areas of soils are potentially remobilized regularly and continue to be a major source of $\mathrm{Hg}$ and TOM to reservoirs.

In summary, combination of ${ }^{210} \mathrm{~Pb}$ age dating, use of TOM biomarkers, and measurements of $\mathrm{T}-[\mathrm{Hg}]$ in lake sediments demonstrate that large increases in

Table 1 Mass normalized concentration of biomarkers used as end-member in the mixing-model (mg g dry wt $\left.{ }^{-1}\right)$

\begin{tabular}{llcc}
\hline & $\lambda 6$ & $\Sigma \mathrm{V}$ & $3,5 \mathrm{Bd}$ \\
\hline Surface organic horizon $(n=18)$ & $12.9 \pm 3.6$ & $6.5 \pm 2.1$ & $1.1 \pm 0.4$ \\
Deep mineral horizon $(n=28)$ & $0.12 \pm 0.05$ & $0.11 \pm 0.09$ & $0.08 \pm 0.05$ \\
\hline
\end{tabular}

Carbon-normalized yields of the sum of lignin-derived vanillyl and syringyl oxidation byproducts: $\lambda 6\left(\mathrm{mg} 100 \mathrm{mg} \mathrm{OC}^{-1}\right.$ ), the sum of vanillyl $\Sigma \mathrm{V}\left(\mathrm{mg} 100 \mathrm{mg} \mathrm{OC}^{-1}\right)$, and 3,5-dihydroxybenzoic acid (mg $100 \mathrm{mg} \mathrm{OC}^{-1}$ ) 
$[\mathrm{Hg}]$ in sediments were a result of flooding of largescale terrestrial areas included in the reservoir. Based in detailed TOM biomarker characterization, the origin of TOM was tracked to originate from surface litter and soil, and we conclude that this was also the major source for $\mathrm{Hg}$ because surface organic horizons and upper soils enriched in $\mathrm{Hg}$ were prone to erosion and subsequent re-sedimentation in the reservoirs. Enrichments in TOM and $\mathrm{Hg}$ levels are still observed forty years after flooding, suggesting a long-term disruption of TOM and $\mathrm{Hg}$ loadings after reservoir impoundment. Differences in TOM and $\mathrm{Hg}$ loads between the two flooded Sandgirt and Gabbro lakes demonstrate the importance of the flooded area, surrounding vegetation, and watershed slope for $\mathrm{Hg}$ and TOM dynamics.

Acknowledgments We thank Sophie Chen and Isabelle Rheault for their assistance in the laboratory. We also thank Bassam Ghaleb for his support in radiometric measurements analysis and interpretation, Jean Carreau and Véronique Fournier for the sampling work and Arnaud Mansat for map editing. We are grateful to Karsten Kalbitz and two anonymous reviewers whose comments greatly improve the manuscript. This research was supported by the Collaborative Mercury Research Network (COMERN), financed by the Natural Sciences and Engineering Research Council of Canada (NSERC). Support for D. Obrist was provided by an EPA Science-To-Achieve-Results (STAR) Grant (R833378).

\section{References}

Abril JM (2003) A new theoretical treatment of compaction and the advective-diffusive processes in sediments: a reviewed basis for radiometric dating models. J Paleolimnol 30: 363-370

Appleby PG, Oldfield F (1990) Radioisotope studies of recent lake and reservoir sedimentation. In: Crickmore MJ, Tazioli GS, Appleby PG, Oldfield F (eds) The use of nuclear techniques in sediment transport and sedimentation. UNESCO, Paris, pp 131-167

Bloom N, Fitzgerald WF (1988) Determination of volatile mercury species at the picogram level by low-temperature gas chromatography with cold-vapour atomic fluorescence detection. Anal Chim Acta 208:151-161

Bodaly RA, Hecky RE, Fudge RJP (1984) Increases in fish mercury levels in lakes flooded by the Churchill River diversion, Northern Manitoba. Can J Fish Aquat Sci 41: 682-691

Caldwell CA, Canavan CM, Bloom NS (2000) Potential effects of forest fire and storm flow on total mercury and methylmercury in sediments of an arid-lands reservoir. Sci Total Environ 260:125-133
Caron S, Lucotte M, Teisserenc R (2008) Mercury transfer from watersheds to aquatic environments following the erosion of agrarian soils: a molecular biomarker approach. Can J Soil Sci 88:801-811

Dittmar T, Lara RJ (2001) Molecular evidence for lignin degradation in sulfate-reducing mangrove sediments (Amazônia, Brazil). Geochim Cosmochim Acta 65:1417-1428

Duthie H, Ostrofsky M (1974) Plankton, chemistry, and physics of lakes in the Churchill Falls region of Labrador. J Fish Res Board Can 31:1105-1117

Fitzgerald WF, Engstrom DR, Mason RP, Nater EA (1998) The case for atmospheric mercury contamination in remote areas. Environ Sci Technol 32:1-7

Flynn WW (1968) The determination of low levels of polonium210 in environmental samples. Anal Chim Acta 43:221-227

French KJ, Scruton DA, Anderson MR, Schneider DC (1999) Influence of physical and chemical characteristics on mercury in aquatic sediments. Water Air Soil Pollut 110:347-362

Friedli HR, Radke LF, Payne NJ, McRae DJ, Lynham TJ, Blake TW (2007) Mercury in vegetation and organic soil at an upland boreal forest site in Prince Albert National Park, Saskatchewan, Canada. J Geophys Res 112:G01004

Garcia E, Carignan R (2005) Mercury concentrations in fish from forest harvesting and fire impacted Canadian boreal lakes compared using stable isotopes of nitrogen. Environ Toxicol Chem 24:685-693

Goñi MA, Hedges JI (1995) Sources and reactivities of marinederived organic matter in coastal sediments as determined by alkaline $\mathrm{CuO}$ oxidation. Geochim Cosmochim Acta 59:2965-2968

Goñi MA, Montgomery S (2000) Alkaline CuO oxidation with microwave digestion system: Lignin analyses of geochemical samples. Anal Chem 72:3116-3121

Graydon JA, St Louis VL, Hintelmann H, Lindberg SE, Sandilands KA, Rudd JWM, Kelly CA, Tate MT, Krabbenhoft DP, Lehnherr I (2009) Investigation of uptake and retention of atmospheric $\mathrm{Hg}$ (II) by boreal forest plants using stable $\mathrm{Hg}$ isotopes. Environ Sci Technol 43:4960-4966

Grigal DF (2003) Mercury sequestration in forests and peatlands: a review. J Environ Qual 32:393-405

Grondin A, Lucotte M, Mucci A, Fortin B (1995) Mercury and lead profiles and burdens in soils of Quebec (Canada) before and after flooding. Can J Fish Aquat Sci 52:2493-2506

Hall BD, Louis VL, Rolfhus KR, Bodaly RA, Beaty KG, Paterson MJ, Cherewyk KAP (2005) Impacts of reservoir creation on the biogeochemical cycling of methyl mercury and total mercury in boreal upland forests. Ecosystems $8: 248-266$

Hamilton TF, Smith JD (1986) Improved alpha energy resolution for the determination of polonium isotopes by alphaspectrometry. Appl Radiat Isot 37:628-630

Harris RC, Rudd JWM, Amyot M et al (2007) Whole-ecosystem study shows rapid fish-mercury response to changes in mercury deposition. Proc Natl Acad Sci 104:16586-16591

Hedges JI, Ertel JR (1982) Characterization of lignin by gas capillary chromatography of cupric oxidation products. Anal Chem 54:174-178

Hedges JI, Mann DC (1979) The characterisation of plant tissues by their lignin oxidation products. Geochim Cosmochim Acta 43:1803-1907 
Hernes P, Robinson A, Aufdenkampe A (2007) Fractionation of lignin during leaching and sorption and implications for organic matter "freshness". Geophys Res Lett 34:L17401

Houel S, Louchouarn P, Lucotte M, Canuel R, Ghaleb B (2006) Translocation of soil organic matter following reservoir impoundment in boreal systems: implications for in situ productivity. Limnol Oceanogr 51:1497-1513

Hu FS, Hedges JI, Gordon ES, Brubaker LB (1999) Lignin biomarkers and pollen in postglacial sediments of an Alaskan lake. Geochim Cosmochim Acta 63:1421-1430

Kelly C, Rudd J, Bodaly R, Roulet N, St Louis V, Heyes A, Moore T, Schiff S, Aravena R, Scott K (1997) Increases in fluxes of greenhouse gases and methyl mercury following flooding of an experimental reservoir. Environ Sci Technol 31:1334-1344

Kolka RK, Grigal DF, Verry ES, Nater EA (1999) Mercury and organic carbon relationships in streams draining forested upland/peatland watersheds. J Environ Qual 28:766-775

Louchouarn P, Lucotte M, Mucci A, Pichet P (1993) Geochemistry of mercury in two hydroelectric reservoirs in Quebec, Canada. Can J Fish Aquat Sci 50:269-281

Louchouarn P, Lucotte M, Canuel R, Gagné J, Richard L (1997) Sources and early diagenesis of lignin and bulk organic matter in the sediments of the lower St Lawrence Estuary and the Saguenay Fjord. Mar Chem 58:3-26

Lucotte M, Mucci A, Hillaire-Marcel C, Pichet P, Grondin A (1995) Anthropogenic mercury enrichment in remote lakes of northern Quebec (Canada). Water Air Soil Pollut 80: $467-476$

Meili M (1991) The coupling of mercury and organic matter in the biogeochemical cycle-towards a mechanistic model for the boreal forest zone. Water Air Soil Pollut 80: $467-476$

Munthe J, Hultberg H (2004) Mercury and methylmercury in runoff from a forested catchment-concentrations, fluxes, and their response to manipulations. Water Air Soil Pollut Focus 4:607-618

Nelson S, Johnson K, Kahl J, Haines T, Fernandez I (2007) Mass balances of mercury and nitrogen in burned and unburned forested watersheds at Acadia National Park, Maine, USA. Environ Monit Assess 126:69-80

Obrist D, Johnson DW, Lindberg SE, Luo Y, Hararuk O, Bracho R, Battles JJ, Dail DB, Edmonds RL, Monson RK, Ollinger SV, Pallardy SG, Pregitzer KS, Todd DE (2011) Mercury distribution across 14 U.S. forests. Part I: spatial patterns of concentrations in biomass, litter, and soils. Environ Sci Technol 45:3974-3981

Pempkowiak J, Tylmann W, Staniszewski A, Golebiewski R (2006) Lignin depolymerization products as biomarkers of the organic matter sedimentary record in $210 \mathrm{~Pb}-137 \mathrm{Cs}-$ dated lake sediments. Org Geochem 37:1452-1464

Pichet P, Morrison K, Rheault I, Tremblay A (1999) Analysis of total mercury and methylmercury in environmental samples. In: Lucotte M, Schetagne R, Thérien N, Langlois C,
Tremblay A (eds) Mercury in the biogeochemical cycle, natural environments and hydroelectric reservoirs of Northern Québec. Springer, New York, pp 41-52

Pokharel AK, Obrist D (2011) Fate of mercury in tree litter during decomposition. Biogeosciences 8:2507-2521

Prahl FG, Ertel JR, Goñi MA, Sparrow MA, Eversmeyer B (1994) Terrestrial organic carbon contributions to sediments on the Washington margin. Geochim Cosmochim Acta 58:3035-3048

Rasmussen PE (1994) Current methods of estimating atmospheric mercury fluxes in remote areas. Environ Sci Technol 28:2233-2241

Ravichandran M (2004) Interactions between mercury and dissolved organic matter-a review. Chemosphere 55: 319-331

Rencz AN, O’Driscoll NJ, Hall GEM, Peron T, Telmer K, Burgess NM (2003) Spatial variation and correlations of mercury levels in the terrestrial and aquatic components of a wetland dominated ecosystem: Kejimkujik Park, Nova Scotia, Canada. Water Air Soil Pollut 143:271-288

Schuster E (1991) The behavior of mercury in the soil with special emphasis on complexation and adsorption processes-a review of the literature. Water Air Soil Pollut 56:667-680

Shotbolt LA, Thomas AD, Hutchinson SM (2005) The use of reservoir sediments as environmental archives of catchment inputs and atmospheric pollution. Prog Phys Geogr 29:337-361

St Louis V, Kelly C, Duchemin E, Rudd J, Rosenberg D (2000) Reservoir surfaces as sources of greenhouse gases to the atmosphere: a global estimate. Bioscience 50:766-775

St Louis V, Rudd J, Kelly C, Bodaly RA, Paterson M, Beaty KG, Hesslein RH, Heyes A, Majewski RA (2004) The rise and fall of mercury methylation in an experimental reservoir. Environ Sci Technol 38:1348-1358

Teisserenc R (2009) Dynamique de la matière organique terrigène et du mercure dans les lacs et reservoirs boréaux. $\mathrm{Ph}$.D. Thesis, Université du Québec à Montréal, Montreal

Teisserenc R, Lucotte M, Houel S, Carreau J (2010) Integrated transfers of terrigenous organic matter to lakes at their watershed level: a combined biomarker and GIS analysis. Geochim Cosmochim Acta 74:6375-6386

Teisserenc R, Lucotte M, Houel S (2011) Terrestrial organic matter biomarkers as tracers of $\mathrm{Hg}$ sources in lake sediments. Biogeochemistry 103:235-244

Ugolini FC, Reaner RE, Rau GH, Hedges JI (1981) Pedological, isotopic, and geochemical investigations of the soils at the boreal forest and alpine toundra transition in northern Alsaka. Soil Sci 131:359-374

Verdon R, Brouard D, Demers C, Lalumiere R, Laperle M, Schetagne R (1991) Mercury evolution (1978-1988) in fishes of the La Grande hydroelectric complex, Quebec, Canada. Water Air Soil Pollut 56:405-417 